\title{
Ikääntyneet mukaan mediakasvatukseen
}

\author{
PÄIVI HAKKARAINEN, PIRKKO HYVÖNEN, TERO LUKSUA \& OUTI LEINONEN
}

Ketkä ovat nykypäivän mediakulttuurin ikääntyneitä: työelämän yli 45vuotiaat vai työelämästä eläkkeelle siirtyneet? Mielenkiintoinen tutkimusaihe sekin, toteavat artikkelin kirjoittajat. Kirjoittajat luovat katsauksen siihen, miten ikääntyneet ovat edustettuina viimeaikaisessa mediakasvatuskirjallisuudessa ja -tutkimuksessa ja toteavat ikääntyneet jokseenkin unohdetuksi väestöryhmäksi. Tietotekniikan osaaminen koetaan nykyisyyden symbolina. Sen riittävä hallinta tuo ajassa ja kulttuurissa mukana olemisen tunnetta ja siitä syrjäytyminen häpeää. Mutta symbolista arvoa tärkeämpää on tietotekniikan välineellinen merkitys.

$\mathrm{J}$ atkamme ja täydennämme näkökulmassamme 2000-luvun suomalaisessa mediakasvatuskirjallisuudessa harjoitettua suomalaisen mediakasvatuksen tilan pohdintaa ja analyysia. Mediakasvatusta on kirjallisuudessa ansiokkaasti analysoitu ja luokiteltu sen perusteella, minkä tieteenalan sisältä tutkittavat ilmiöt nousevat, sekä sen perusteella, mihin käytännön kysymyksiin, millä tavalla ja millaisin painotuksiin tutkimus kohdistuu (esim. Kupiainen, Sintonen \& Suoranta 2007; Vesterinen, Vahtivuori-Hänninen, Oksanen, Uusitalo \& Kynäslahti 2006; Kotilainen \& Suoranta 2005). Haluamme nostaa keskusteluun vielä yhden näkökulman 2000-luvun suomalaiseen mediakasvatukseen: ikääntyneiden henkilöiden heikon tai kokonaan puuttuvan osallisuuden.

Näkökulma sisältyy itse asiassa jo siihen, että digitaaliset pelit sekä niin sanottu sosiaalinen media ja Web $2.0^{1}$ on esitetty teknologisesta näkökulmasta tämän hetken mediakasvatuksen erityispiirteeksi (ks. Kupiainen, Sintonen \& Suoranta 2007). Digitaaliset pelit ja Web 2.0 ovat pääsääntöisesti osa lasten, nuorten ja aikuisten elämismaailmaa. Kupiainen, Sintonen ja Suoranta (emt.) toteavatkin, että lasten ja nuorten medialta suojelun näkökulma on ollut korostetusti esillä 2000-luvun suomalaisessa mediakasvatustoiminnassa (ks. myös Liikenne- ja viestintäministeriö 2008). Emme väitä, etteikö lasten ja nuorten mediakasvatus olisi tärkeää, ensisijaistakin. Lasten ja nuorten valo- kiila ei kuitenkaan saisi jättää ikääntyneitä hämärään, kuten nyt näyttää käyneen. Meistä on alkanut vaikuttaa siltä, että mediakasvatus 2000-luvun Suomessa on ensisijaisesti lasten ja nuorten sekä kasvavassa määrin myös aikuisten (ks. Aikuiskasvatus 3/2006; Herkman 2007) mediakasvatusta. Ikääntyneiden mediakasvatusta se ei vielä riittävästi ole.

Ikääntyneillä voidaan viitata hyvinkin eri-ikäisiin ihmisiin riippuen siitä, mitä ikääntymisen aluetta tutkitaan: työelämän tutkimuksissa 45-vuotias voi olla ikääntynyt, kun toisaalta ihminen saattaa kokea itsensä ikääntyneeksi vasta 85-vuotiaana (ks. Raitanen, Hänninen, Pajunen \& Suutama 2004). Mielenkiintoista olisikin tutkia, ketkä ovat tämän päivän mediakulttuurin ikääntyneitä - 45-vuotiaatko? Toisaalta voidaan kysyä, minkälaisissa mediakasvatuksen konteksteissa ikääntynyt on tarpeen erottaa muista aikuisista. Esimerkiksi kansalaisuudesta puhuttaessa aikuisuus voi riittää toimijoiden iän tai elämänkokemuksen määrittämiseen.

\section{Ikääntyneiden representaatiot mediakasvatuskirjallisuudessa}

Representaatio on yksi mediakasvatuksen keskeisistä käsitteistä (esim. Suoranta \& Ylä-Kotola 2000, 71; Kupiainen 2005, 76) ja sen avulla voimme pohtia, miten suomalainen 2000-luvun mediakasvatus- 
kirjallisuus esittää ja tuottaa kuvaa mediakasvatuksesta. Edellä esitetyn kokemusperäisen, ikääntyneiden heikkoa osallisuutta koskevan havaintomme tueksi olemme lukeneet joukon keskeisiä suomalaisia 2000-luvun julkaisuja, joissa mediakasvatuksen sisältöä ja tilaa on kuvattu, arvioitu ja luokiteltu (Taulukko 1). Näistä julkaisuista olemme etsineet ikääntyneiden osallisuutta mediakasvatuksessa, niin käytännön toteutuksessa kuin tutkimuksessakin. Kotimaisia yliopistollisia opetusohjelmia (ks. Kupiainen 2005, 83) emme ole analysoineet. Voimme vain luottaa ja toivoa, että opetusohjelmien sisällöissä ikääntyneet ovat kasva- vassa määrin osallisina. Omien yliopistojemme, Lapin yliopiston kasvatustieteiden tiedekunnan mediakasvatuksen koulutusohjelmassa sekä Oulun yliopiston koulutusteknologian opetuksessa tähän on reagoitu.

Julkaisuissa kuuluvat pysyviin virkoihin perustuvaa mediakasvatustoimintaa harjoittavan Lapin yliopiston sekä Helsingin yliopiston mediakasvattajien äänet sekä mediakasvatuksen opetusta järjestävien Tampereen yliopiston, Åbo Akademin sekä Jyväskylän yliopiston mediakasvattajien äänet (ks. myös Kupiainen, Sintonen \& Suoranta 2007). Lisäksi aineistoon on valittu opetusminis-

Taulukko 1. Näkökulmaa varten tarkastellut 2000-luvun julkaisut

\section{Kirjoittaja/-t}

Suoranta, J. \& Ylä-Kotola, M.

Sintonen, S.

Kotilainen, S.

Suoranta, J.

Kotilainen, S. \& Sintonen, S. (toim.)

Ruokamo, H.

nen

va-

Kupiainen, R.

2005

Vesterinen, O., Vahtivuori-Hänninen, S., Oksanen, U., Uusitalo, A. \& Kynäslahti, H. 2006

Aikuiskasvatus 3/2006

OPM 29/2007

Kynäslahti, H., Kupiainen, R. \& Lehtonen, M. (toim.)

Kotilainen, S. \& Rantala L.

Herkman, J.
Julkai-

suvuosi Julkaisu

2000 Mediakasvatus simulaatiokulttuurissa

2001 Mediakasvatus ja sen musiikilliset mahdollisuudet

2001 Mediakulttuurin haasteita opettajankoulutukselle

2003 Kasvatus mediakulttuurissa. Mitä kasvattajan tulee tietää?

2005 Mediakasvatus 2005. Kansalliset kehittämistarpeet. Oikeusministeriön julkaisuja 5/2005.

2005 Näkökulmia mediakasvatuksen opetukseen ja tutkimukseen.Teoksessa A. Niikko, M.-L. Julku\& M.-B. Kentz (toim.) Osaamisen jakamista kastustieteessä

Mediakasvatuksen eetos. Fenomenologinen tutkimus mediakasvatuksen etiikasta

Mediakasvatus median ja kasvatuksen alueena Deskriptiivisen mediakasvatuksen ja didaktiikan näkökulmia. Kasvatus 2/2006.

Media aikuisen kasvattajana

2007 Ehdotus toimenpideohjelmaksi mediataitojen ja -osaamisen kehittämiseksi osana kansalais-ja tietoyhteiskuntataitojen edistämistä. Opetusministeriön työryhmämuistioita ja selvityksiä 29/2007.

Näkökulmia mediakasvatukseen. Mediakasvatusseuran julkaisuja 1/2007.

Yhteiskunnallista mediakasvatusta tietoverkossa Teoksessa P. Arola \& P. Sallila (toim.) Koulussa kansalaiseksi. Opettaja ja aktiivinen koulukulttuuri 2007 Kriittinen mediakasvatus 
teriön vuonna 2006 asettaman työryhmän (OPM 2007) tuottama "Ehdotus toimenpideohjelmaksi mediataitojen ja -osaamisen kehittämiseksi osana kansalais- ja tietoyhteiskuntataitojen edistämistä” -työryhmämuistio, vuonna 2005 perustetun Mediakasvatusseuran julkaisusarjan tähänastiset kaksi julkaisua sekä Aikuiskasvatus-lehden teemanumero Media aikuisen kasvattajana (3/2006). Olemme tarkastelleet keskeisimpiä julkaisuja (vrt. Kupiainen, Sintonen \& Suoranta 2007), mutta emme väitä aineistomme olevan kaikenkattava katsaus suomalaisen mediakasvatuksen sisältöjä sekä tilaa kuvaavista ja arvioivista teoksista. Kartoituksemme tulokset kertovat ikääntyneiden osallisuuden pääpiirteet, vaikkei kartoitus tieteellisen tutkimuksen kriteerejä täytäkään.

Olemme soveltaneet Herkmanin (2007, 101-102) esittämiä tukikysymyksiä kielellisten mediaesitysten analyysiin kysymällä aineistoltamme: ”Kuinka mediakasvatusta kuvataan?, Kuka/ketkä ovat mediakasvatuksen käytännön toteutuksen kohteita?, ”Kuka/ketkä ovat mediakasvatuksen toimijoita?” ja "Kuka/ketkä ovat mediakasvatuksen tutkimuksen kohteena?”. Seuraavaksi esittelemme kartoituksemme tuloksia.

\section{Monitieteisestä mediakasvatuksesta puuttuvat ikääntymistä tutkivat tieteet}

Valitsemissamme julkaisuissa mediakasvatusta kuvataan monitieteisenä (esim. Kotilainen \& Suoranta 2005; Vesterinen ym. 2006; Kupiainen 2005), tieteiden välisenä, tieteiden ja taiteiden välisenä sekä tiede- ja taiderajat ylittävänä tieteenä (Ruokamo 2005; Suoranta \& Ylä-Kotola 2000). Mediakasvatuksen perustieteiksi nimetään viestintä- ja kasvatustieteet samalla kuitenkin korostaen, että mediakasvatuksellista tutkimusta tehdään useissa muissakin tieteissä, kuten sosiologiassa, sosiaalipsykologiassa, psykologiassa, kirjallisuustieteessä ja kauppatieteissä. (Kotilainen \& Suoranta 2005, 74.) Mediakasvatus kuvataan myös kasvatustieteen ja mediatieteen yhtymäkohdaksi (Sintonen 2001, 85-86) sekä kasvatustieteen ja mediatieteen osaksi (Suoranta ja Ylä-Kotola 2000, 10, 23). Lisäksi erotellaan seuraavat mediakasvatukselliset "ilmiökeskeiset tutkimusalueet": lapsi- ja nuorisotutkimus, kulttuurintutkimus, elokuvatutkimus, tieto- ja viestintäteknologian tutkimus, taidekasvatuksen tutkimus, informaatiotutkimus ja kuluttajatutkimus (Kotilainen \& Suoranta 2005, 74).

Mediakasvatus ei valitsemissamme julkaisuis- sa näyttäydy riittävän monitieteisenä. Yhdessäkään julkaisussa ei mainita ikääntymiseen kohdistuvia tieteitä aloina, joilla mediakasvatuksellista tutkimusta tehdään ja toisaalta aloina, joilla voisi olla hedelmällisiä yhtymäkohtia mediakasvatukseen. Esimerkiksi gerontologiaa (ml. sosiaali-, psyko- ja kasvatusgerontologia ${ }^{2}$ ) ja geropsykologiaa (ks. Raitanen, Hänninen, Pajunen \& Suutama, 2004) ei tarkastelumme kohteena olevassa kirjallisuudessa mainita. Sen sijaan varhaiskasvatus sekä lapsi- ja nuorisotutkimus tulevat mainituiksi mediakasvatukseen liittyvinä tieteenaloina (esimerkiksi Kynäslahti, Kupiainen \& Lehtonen 2007).

\section{Määritelmät ja käytäntöjä kuvaavat esimerkit ovat ristiriidassa}

Mediakasvatuksen käsite on vakiintunut suomalaiseen käytäntöön 2000-luvulla, vaikkakaan yhtä selkeää määritelmää sille ei voida antaa (Kupiainen, Sintonen \& Suoranta 2007). Tässä yhteydessä tarkoituksenamme ei ole yleisesti kertoa mediakasvatuksen erilaisista määritelmistä, vaan olemme sen sijaan kiinnostuneita siitä, millainen on ikääntyneiden representaatio näissä määritelmissä. Mediakasvatuksen määritelmissä mediakasvatuksen käytännön toiminnan ja tutkimuksen kohteet esitetään niin, että niihin voi lukea kuuluvaksi myös ikääntyneet. Käytännössä tämä tehdään puhumalla "meistä”, "ihmisistä”, ”yksilöistä”, ”yhteisöistä”, ,"kansalaisista”, "opiskelijoista” tai ”toimijoista”, kuten seuraavissa esimerkeissä (kirjoittajien kursivointi):

Yleisimmin sanoen mediakasvatuksessa kehitetään mentaalisia ja käsitteellisiä välineitä ja pedagogisia käytänteitä, joilla ihmiset kykenevät toimimaan ja lisäämään toimintakykyisyyttään ja -mahdollisuuksiaan simulaatiokulttuurissa (Suoranta \& Ylä-Kotola 2000, 10-11).

Mediakasvatuksen tavoitteena on tuottaa osallistuvia, itseään sujuvasti ilmaisevia ja kriittisiä kansalaisia, jotka päivittävät jatkuvasti myös viestintäteknistä osaamistaan (Tuominen \& Mustonen 2007, 137).

Mediakasvatuksen tutkimuskysymykset sijoittuvat monelle eri tieteenalalle. Kaikissa niissä on kuitenkin yhtenä elementtinä media eli viestimet eri muodoissaan tai median kyllästämä kulttuuri (vrt. esim. Kotilainen 2001). Merkittävä yhdistävä elementti on myös yksilön tai yhtei- 
sön suhde mediaan ja mediakulttuurin ilmiöihin, varsinkin kasvuun ja kehitykseen sekä yhteiskunnalliseen ja poliittiseen vaikuttamiseen. (Kotilainen \& Suoranta 2005, 73.)

Ikääntyneet voidaan sisällyttää myös niihin mediakasvatuksen representaatioihin, joissa erityisesti aikuiset ovat kuvattuina. Valitsemissamme julkaisuissa vain muutamissa (ks. Aikuiskasvatus 3/2006; Herkman 2007) aikuiset kuvataan mediakasvatuksen kohteiksi muutoin kuin lasten ja nuorten vanhempina. Aikuisten mediakasvatus rinnastetaan kuluttajavalistukseen, perehtymiseen media- ja tietopalveluihin sekä mediaa ja mainosalaa koskevaan sääntelyyn (Mustonen 2006). Ikääntyneisiin viitataan silloin kun tavoitteena on tarkastella koko elämänkaarta mediakasvatuksen kontekstissa, kuten Mustonen (emt.) tekee korostaessaan mediakasvatusta koko elämän pituisena prosessina. Ikääntyneen arvo tässä prosessissa näyttäytyy muiden muassa elämänkokemuksen ansiosta. Hänen arvonsa konkretisoituu sukupolvien välisessä vuorovaikutuksessa, sillä ikääntynyt voi yhdistää perheenjäseniä mediavälineiden kautta (emt.). Vaikka ikääntyneet ovat huomattava median käyttäjä- ja tuottajaryhmä, vain yhdessä tarkastelemistamme julkaisuista mediakasvatuksen määritelmässä ikääntyneet tulevat erikseen mainituiksi:

Mediaa tarkastellaan osana 1) opetusta, opiskelua ja oppimista, 2) lasten, nuorten, aikuisten ja ikä-ihmisten elämää sekä 3) yhteiskuntaa ja maapalloistuvaa kulttuuria. Mediaa tarkastellaan sen 1) tuottamisen ja 2) vastaanottamisen kautta sekä 3) kriittisen tarkastelun kohteena. (Ruokamo 2005, 132-133.)

Tarkastelemissamme julkaisuissa ikääntyneet ovat osallisina mediakasvatuksen yleisissä määritelmissä. Ristiriita syntyy siitä, että käytännön toimintaa ja tutkimusta kuvaavat esimerkit kohdistuvat kuitenkin yksinomaan lapsiin ja nuoriin. Julkaisuissa analysoidaan mm. nuorten kansalaissivustoa (Kotilainen \& Rantala 2007), nuorille tai aikuisille suunnattuja mediatuotteita (Herkman 2007) sekä kuvataan lasten ja nuorten mediakasvatukseen liittyviä hankkeita (esimerkiksi Niinistö \& Ruhala 2007). Mediakasvatusta tarkastellaan pääosin osana kouluopetusta, vaikka toisaalla todetaan, että mediakasvatuksessa on pyritty laventamaan pedagogiikan käsitettä myös muihin kuin muodolli- sen koulutuksen piirissä tapahtuviin koulutuksen käytäntöihin (Kotilainen \& Suoranta 2005, 73). Poikkeuksena mainittakoon Suorannan (2006) aikuisten mediatajua käsittelevä artikkeli, jonka empiirisenä aineistona on käytetty päiväkirjoja, joissa suomalaiset kuvaavat elämäänsä mediassa yhden päivän ajan. Tähän aineistoon sisältyvät myös ikääntyneet.

Tarkastelemamme kirjallisuuden perusteella kirjastoista näyttää löytyvän aloitteellisuutta ikääntyneiden osallistamiseen mediakasvatuksessa. Kirjastoa kuvataan kaikenikäisten matalakynnyksisenä, tunnustettuna, suosittuna ja siten otollisena paikkana mediakasvatukselle (Haavisto 2007). Todellisuudessa kirjasto onkin juuri sitä: suosituin ja tasa-arvoisin yleisöinstituutio (Liikkanen, Hanifi \& Hannula 2005). Kirjaston mediakasvatustoimintaan liittyvästä artikkelista löytyi myös toinen aineiston kahdesta isovanhempien maininnasta:

Mediakasvatuksen muiden toimijoiden kannalta kirjastojen vahvuus on niiden tunnustettu ja suosittu asema. Siksi niitä kannattaa pyytää mukaan toimintaketjuihin, joissa halutaan esim. tavoittaa mahdollisimman monet vanhemmat ja isovanhemmat (Haavisto 2007, 121).

Aineistostamme löytyy myös julkaisu, jossa on kahdesti mainittu ikääntyneiden osallistamisen tärkeys. Tosin näistä toisessa ikääntyneet nähdään rajatusta näkökulmasta vain isovanhempina:

Työryhmämme mielestä mediakasvatus kattaa kaikki elämänkulun vaiheet ja sen tärkeitä kohderyhmiä ovat lasten ja nuorten lisäksi kasvattajat, ikääntyneet (isovanhemmat) ja muut aikuiset (kansalaiskasvatus). (Kotilainen \& Sintonen 2005, 81).

Keskustelimme lähinnä lasten ja nuorten mediakasvatuksesta, mutta mielestämme myös ikäihmiset tarvitsevat mediakasvatusta. (emt., 84).

Tähän mennessä olemme todenneet, että ikääntyneiden representaatio mediakasvatuksen käytännön toteutuksen ja tutkimuksen kohteena on ohut. Entä kuvataanko ikääntyneet muissa mediakasvatuksen toimijarooleissa kuin edellä esitetyssä isovanhemman roolissa? OPM:n työryhmämuistiossa $(2007,12)$ määritellään mediakasvatuksen toimijoiksi Suomessa vuonna 2007 erilaiset työelämässä olevat ammattiryhmät (nuorisotyöntekijät, 
kirjastoammattilaiset, median edustajat, tutkijat, psykologit ja psykiatrit, opettajat, varhaiskasvattajat) sekä näiden ammattialojen opiskelijat. Lisäksi mediakasvatuksen toimijoiksi kuvataan vanhemmat - ei kuitenkaan isovanhempia. Muistiossa sisällytetään kansalaistoimijat mm. eri järjestöissä mediakasvatuksen toimijoiksi, mikä osallistaa myös ikääntyneitä.

\section{Ikääntyneiden osallistaminen mediakasvatukseen on tärkeää}

Euroopan unionin alueiden komitean julkaisema lausunto aiheesta "Hyvä ikääntyminen tietoyhteiskunnassa” vahvistaa väitettämme ikääntyneiden osallistamisen tärkeydestä mediakasvatuksessa. Lausunnon mukaan EU:n tasolla ei ole riittävästi ymmärretty e-learning-käsitteen, jonka katsomme sisältyvän mediakasvatukseen, koskevan esimerkiksi ikääntyneiden työelämästä siirtyneiden henkilöiden tarpeita. (EU 2008.) Sosiaalisesti aktiivinen ja luova ikääntynyt hallitsee arjen, voi vaikuttaa, olla sosiaalisessa vuorovaikutuksessa ja käyttää luovuuttaan itselleen merkityksellisillä tavoilla. Ei voida kuitenkaan ajatella, että kyseessä olisi vain ikääntyneen oma valinta - ollako aktiivinen mediaa hyödyntävä toimija ja osallistuja vai ei? Yhteiskunta haastaa, velvoittaa, jopa pakottaa siihen (ks. Aula-Matila 1999; Hyvönen 2002; Sankari 2004).

Liikenne- ja viestintäministeriön (2007) viestintäpoliittisen strategian yksi keskeisistä tavoitteista on osallisuuden edistäminen. Lasten, nuorten ja ikääntyneiden huomioon ottaminen nostetaan erityiseksi haasteeksi. Väestön ikääntyminen luo tarvetta uusille arkipäivää tukeville teknologioille ja palveluille. Ikääntyvän väestön syrjäytymisriskin ennustetaan kasvavan. Yhtenä mekanismina tässä prosessissa on julkisten palvelujen siirtyminen verkkoon. Keskeisinä haasteina mainitaan muiden muassa kansalaisten tietoturvatietoisuuden ja -osaamisen sekä tietotekniikkaosaamisen kehittymisen tukeminen sekä luottamuksen synnyttäminen uutta tekniikkaa kohtaan. Strategiassa korostetaan lisäksi, että viihdepalveluiden merkitys korostuu tulevaisuudessa.

Viimeisen 20 vuoden aikana on mediatarjonta moninkertaistunut ja ikääntyneet ovat median suurkuluttajia. Vaikka radion kuuntelu on hieman vähentynyt, käyvät yli 65-vuotiaat elokuvissa ja katsovat televisiota enemmän kuin edellisenä vuosikymmenenä (Liikkanen ym. 2005). Vuonna 2007 suomalaiset katselivat televisiota keskimäärin 2 tuntia 46 minuuttia päivässä. Eniten, eli noin 4 tuntia 7 minuuttia päivässä, television parissa viettivät aikaa 65 vuotta täyttäneet. Radiota suomalaiset kuuntelivat vuonna 2007 keskimäärin 3 tuntia 16 minuuttia päivässä. Eniten, eli noin 4 tuntia 24 minuuttia päivässä, radiota kuuntelivat 65 vuotta täyttäneet. (Finnpanel 2008.) Suomalaisten ikääntyneiden Internetin käyttö on lisääntynyt voimakkaasti vuosien 2001-2007 välisenä aikana. Kun koko väestöstä 79 prosenttia käyttää Internetiä, on 50-59-vuotiaiden osuus lähes samansuuruinen. 60-74-vuotiaista Internetiä käyttää liki 40 prosenttia. Kypsän iän sukupolvi ei enää vierasta myöskään Internetin kautta ostamista, sillä verkkokauppahankintojen määrät ovat kasvaneet. Myös matkapuhelimen käyttö on yleistä, noin 90 prosenttia ikääntyneistä kantaa kännykkää mukanaan. (Tilastokeskus 2007.)

\section{Ikääntyneiden mediakasvatus?}

Lopuksi haluamme tuoda esiin joitakin mediakasvatuksen tutkimuksen ja käytännön toteutuksen kannalta mielenkiintoisia tutkimustuloksia. Ikääntyneiden median käyttöön sekä tieto- ja viestintätekniikan, erityisesti tietokoneen käyttöön kohdistuvaa tutkimusta on Suomessa tehty lähinnä 1990luvun loppupuolelta alkaen. Sitä ei kuitenkaan ole otettu mukaan lapsi- ja nuorisovoittoiselle mediakasvatuksen kentälle. Se ei myöskään sisälly tarkastelemamme mediakasvatuskirjallisuuden mediakasvatuksesta tuottamaan representaatioon.

Aula-Matilan (1999) sosiaalipsykologian pro gradu -tutkimuksessa tarkasteltiin 62-83-vuotiaiden ( $\mathrm{N}=7)$ ikäihmisten tietotekniikalle antamia merkityksiä. Tietokoneen käyttö merkityksellistyi sekä huvina että hyötynä. Tutkimuksen ikääntyneet muodostivat heterogeenisen ryhmän, jota yhdisti tietotekniikan kokeminen ensisijaisesti haasteeksi. Hyvösen (2002) aikuiskasvatustieteen pro gradu -tutkimuksessa selvitettiin, miten 63-73-vuotiaat eläkkeellä olevat opettajat $(\mathrm{N}=6)$ oppivat käyttämään omaa tietokonettaan ja mihin he sitä käyttävät. Tutkittavat olivat osallistuneet yhteensä yli 20 ikääntyneille suunnatulle tietotekniikkakurssille. Mielenkiintoista mediakasvatuksenkin näkökulmasta on se, että he olivat osallistuneet samalle kurssille kahteen, jopa kolmeen kertaan. Osoittautui, että opetus ei riittävästi vastaa oppijoiden tarpeisiin ja taitotasoon. Oppimisen kannalta keskeistä oli henkilökohtaisten tukihenkilöiden apu (ks. 
myös Mellor, Firth \& Moore 2008). Parhaiten tukihenkilöitä löytyi sukulaislapsista tai naapuruston nuorisosta. Ikääntyneiden tukihenkilöinä voivat toimia myös toiset, osaavammat ikääntyneet, kuten Hirven (2001) proseminaaritutkimuksessa. Sosiaalisen vuorovaikutuksen lisääminen ja oman tietotaidon ylläpitäminen, elämänsisällön rikastuttaminen sekä yhteiskunnallinen hyödyllisyys motivoivat Hirven tutkimuksessa mukana olleita vastaajia tuutoroimaan tietotekniikkakursseilla.

Sankarin (2004) sosiologian alan väitöskirja osoittaa, että osaaminen ja opettelu tuovat ikääntyneelle ajassa ja kulttuurissa mukana olemisen tunnetta, sillä tietotekniikan osaaminen koetaan nykyisyyden symbolina. Sankarin haastateltavat muistuttavat, että symbolista arvoa tärkeämpää on kuitenkin tietotekniikan välineellinen merkitys. Tutkimus osoittaa myös sen, etteivät kaikki ikääntyneet halua tai voi opetella tietokoneen käyttöä. Selwyn (2004) tuo esiin, että tietokoneesta on tullut siinä määrin merkittävä tehokkuuden ja osallisuuden symboli, että taitamattomuus sen käytössä voi aiheuttaa ikääntyneille häpeän tunteita. Ikääntyneet voivat kokea myös ambivalenttisia tunteita tieto- ja viestintätekniikkaa kohtaan: yhtäältä yhteiskunta odottaa valmiuksia sen käytössä, mutta toisaalta sille voi olla vaikea löytää todellista käyttöä arjessa. Selwynin mielestä tärkeää olisi tässä tilanteessa tutkia syitä, joiden vuoksi ikääntyneet eivät käytä uutta tieto- ja viestintätekniikkaa sekä toisaalta tämän seurauksia.

Niemelän (2006) tieteidenvälisessä väitöskirjassa ikääntyneiden informaatiokäyttäytymisestä esitetään tuloksena uusi käsite: toimintaan aktivoituminen. Niemelän mukaan media aktivoi eläkeläisiä toimimaan arkipäivässä raamittamalla ja rytmittämällä arkista olemista ja tekemistä. Media on moniulotteisesti mukana arjessa, esimerkiksi päiväohjelman organisoinnissa (lehden luku, TV:n katselu), ravinnossa (ruokaohjeiden etsintä), kielitaidon ylläpitämisessä, yhteiskunnalliseen keskusteluun osallistumisessa, sanaristikkojen tekemisessä, kilpailuihin osallistumisessa, pelaamisessa sekä hiljentymisessä.

Vaikka tilastot ja tutkimukset osoittavat, että ikääntyneet käyttävät tietoverkkoja monin tavoin elämässään, liittyy käyttöön useita ongelmia (ks. esim. Aula 2005; Hyvönen 2002), jotka tulisi ottaa huomioon nykyistä enemmän. Aula (emt.) selvitti käytettävyystutkimuksen avulla ikääntyneiden tietokoneen käytön oppimista. Vaikka ikääntyneet selvisivät heille annetuista tehtävistä, tuottivat esimerkiksi tekstin editointi, web:n rakenteen ymmärtäminen sekä käytetty terminologia ongelmia. Myös Hyvösen tutkimuksen (emt.) vastaajat korostivat, että tietokoneen käyttäjän on selvittävä kolmen kielen integraatiossa: tieto- ja viestintäteknologian, englannin ja suomen.

Tuorilan ja Kyrön tutkimuksessa (2005) selvitettiin, millaisia hyvinvointiin vaikuttavia seurauksia Internet-asioinnilla on yli 50-vuotiaille henkilöille. Tutkijat toteavat, että Internet-asiointi voi aiheuttaa myös alueellista epätasa-arvoistumista. Alueille, joilla ei enää ole perinteisiä palveluja, voivat jäädä asumaan vain ne, joilla on mahdollisuuksia hoitaa asiointinsa Internetin kautta. Suuri osa tutkituista ikääntyneistä näki Internet-asioinnin vähentävän perinteisen asioinnin edellyttämää liikkumista sekä sen kuntoa ylläpitävää vaikutusta. Toisaalta potentiaalisten Internetin käyttäjien osuus oli suurin terveydentilansa huonoksi kokevien ryhmässä. Jos Internetin kustannukset olisivat nykyistä pienemmät, lisääntyisi sen käyttäminen asiointiin tutkijoiden mukaan eniten huonokuntoisten ikääntyvien keskuudessa.

Olemme artikkelissamme tuoneet esille havaintomme ikääntyneiden osallisuuden rajoittuneisuudesta mediakasvatuksessa, siten kuin ikääntyneet tarkastelemassamme kirjallisuudessa representoidaan. Esitämme ikääntyneille laajakirjoisempaa toimijaroolivalikoimaa mediakasvatuksessa. Ikääntynyt henkilö voi olla muun muassa vertaisohjaaja, kasvattaja, pankkivirkailija, mediakulttuurin tallentaja ja tuottaja, kuluttaja, tiedonhakija, isovanhempi, vanhempi, yhteydenpitäjä, leikkijä, viihtyjä, pelaaja, opiskelija, opettaja, kansalaisvaikuttaja tai erilaisten palvelujen asiakas.

Mediakasvatuksen monitieteinen tutkimus, kuten todettua, on liian kapeaa. Ikääntyneisiin kohdistuva mediakasvatuksellinen tutkimus voi kohdistua edellä mainittuihin toimijarooleihin. Lähitulevaisuuden keskeisiä tutkimusteemoja voivat olla median merkitykset esimerkiksi seuraavissa kysymyksissä: "ikääntyneet ja pelaaminen", "ikääntyneet ja sosiaalinen media”, "ikääntyneet verkkoopiskelijoina” tai ”ikääntyneet kuluttajina”. Pidämme omalta osaltamme huolen, että ikääntyneet ovat osallisina opetuksemme ja opintojemme sisällöissä. Jäämme mielenkiinnolla seuraamaan suomalaisen mediakasvatuksen tilaa ja siitä edelleen käytävää keskustelua. 


\section{Viitteet}

1. Sosiaalisella medialla viitataan tietoverkossa toimivaan yhteisöllisesti tuotettuun tai jaettuun mediasisältöön, jossa käyttäjät jakavat keskenään mielipiteitä, näkemyksiä ja kokemuksia (ks. Wikipedia). Sosiaaliseen mediaan sisällytetään yleisesti Web 2.0 -nimikkeen alle kerättyjä palveluja kuten verkkoviestintätyökalut (esimerkiksi Skype, MSN Messenger, TeamSpeak), blogit (esim. Blogger), yhteisöllisen kirjoittamisen palvelut (esimerkiksi Wikipedia, wikit), videoverkkopalvelut (esimerkiksi YouTube), verkkoyhteisöpalvelut (esim. MySpace), kuvajakelu (esim. IRC-Galleria) ja virtuaalimaailmat (esimerkiksi Second Life, Habbo Hotel) (ks. esimerkiksi Laitinen, Ranta \& Rissanen 2007). Sosiaalista media on kuvattu myös ilmaisuilla "vertaismedia” ja ”osallisuusmedia” (Suoranta 2006).

2. ks. esim. [http://www.avoinyliopisto.fi/fi-FI/ Opetustarjonta/StudyUnit.aspx?StudyUnitId=88 e2b0a0-4062-4354-a696-668e72f970d7]

\section{Kirjallisuus}

Aula, A. (2005). User study on older adults' use of the Web and search engines. Universal Access in the Information Society, 4(1), 6781.

Aula-Matila, A. (1999). Tietotekniikka ikäihmisen elämänkokonaisuudessa - "Mitä sinä, vanha ihminen, tommosella teet?" Sosiaalipsykologian pro gradu-tutkielma. Tampereen yliopisto. Saatavilla osoitteessa: http:// kesayo.jyu.fi/geronet/tutkimus-1/ tutkimus_arja_aula-matila.pdf (tarkistettu 24.2.2008)

Aikuiskasvatus 3/2006. Teemanumero Media aikuisen kasvattajana.

EU (2008). Alueiden komitean lausunto aiheesta "Hyvä ikääntyminen tietoyhteiskunnassa”. Euroopan Unionin Virallinen Lehti, C53, 4043. Saatavilla osoitteessa: http://eurlex.europa.eu/LexUriServ/ LexUriServ.do?uri=OJ:C:2008:053:0040:0043:FI:PDF (tarkistettu 20.3.2008)

Finnpanel (2008). Tv:n katselu monipuolistui vuonna 2007. Lehdistötiedote 16.1.2008. Saatavilla osoitteessa: http://www.finnpanel.fi/tulokset/tiedote.php?id=53 (tarkistettu 6.4.2008)
Haavisto, T. (2007). Mediakasvatus ja kirjastot. Teoksessa: H. Kynäslahti, R. Kupiainen \& M. Lehtonen (toim.) Näkökulmia mediakasvatukseen. Mediakasvatusseuran julkaisuja 1/ 2007, 117-121. Saatavilla osoitteessa: http:// www.mediaeducation.fi/publications/ (tarkistettu 20.3.2008)

Herkman, J. (2007). Kriittinen mediakasvatus. Tampere: Vastapaino.

Hirvi, H.-R. (2001). Senioritutoreiden motiiveja ja kokemuksia tutorina toimimisesta. Kasvatustieteen laitos. Jyväskylän yliopisto. Saatavilla osoitteessa: http://kesayo.jyu.fi/geronet/ tutkimus-1/tutkimus_heli-riikka_hirvi.pdf (tarkistettu 26.3.2008)

Hyvönen, P. (2002). Tietoverkot ikääntyneen oppijan voimaantumisprosessissa. Pro gradu -tutkielma. Kasvatustieteiden tiedekunta. Lapin yliopisto.

Kotilainen, S. (2001). Mediakulttuurin haasteita opettajankoulutukselle. Acta Electronica Universitatis Tamperensis; 98. Saatavilla osoitteessa: http://acta.uta.fi/teos.phtml?5158 (tarkistettu 12.5.2008)

Kotilainen, S. \& Rantala, L. (2007). Yhteiskunnallista mediakasvatusta tietoverkossa. Teoksessa: P. Arola \& P. Sallila (toim.) Koulussa kansalaiseksi. Opettaja ja aktiivinen koulukulttuuri. Helsinki: Kansanvalistusseura.

Kotilainen, S. \& Sintonen, S. (toim.) (2005). Mediakasvatus 2005. Kansalliset kehittämistarpeet. Oikeusministeriön julkaisuja 5/2005. Saatavilla osoitteessa: http://www.om.fi/ 31548.htm (tarkistettu 6.4.2008)

Kotilainen, S. \& Suoranta, J. (2005). Mediakasvatuksen kaipuu - ajatuksia alan tutkimuksen kehittämistarpeista. Teoksessa: OM 5/2005. Mediakasvatus. Kansalliset kehittämistarpeet. Oikeusministeriön julkaisuja 5/2005, 7377. Saatavilla osoitteessa: http://www.om.fi/ 31548.htm (tarkistettu 6.4.2008)

Kupiainen, R. (2005). Mediakasvatuksen eetos. Fenomenologinen tutkimus mediakasvatuksen etiikasta. Acta Universitatis Lapponiensis 86. Rovaniemi: Lapin yliopisto, kasvatustieteiden tiedekunta.

Kupiainen, R., Sintonen, S. \& Suoranta, J. (2007). Suomalaisen mediakasvatuksen vuosikymmenet. Teoksessa: H. Kynäslahti, R. Kupiainen \& M. Lehtonen (toim.) Näkökulmia media- 
kasvatukseen. Mediakasvatusseuran julkaisuja $1 / 2007$.

Kynäslahti, H., Kupiainen, R. \& Lehtonen, M. (toim.) (2007). Näkökulmia mediakasvatukseen. Mediakasvatusseuran julkaisuja 1/2007.

Laitinen, K., Ranta, P. \& Rissanen, M. (2007). Sosiaalisen median opetuskäytön mahdollisuudet ja haasteet. Teoksessa: K. Laitinen \& M. Rissanen (toim.) Virtuaalisia yhteisöjä, ajatuksia ja avoimuutta - sosiaalinen media opetuksen ja oppimisen tukena. Sosiaalinen media opetuksen ja oppimisen tukena (SMOOT) -hankkeen selvitys. Kuopio: Kuopion yliopisto, oppimiskeskus, 35-64. Saatavilla osoitteessa: http://www.smoot.fi/ (tarkistettu 27.3.2008)

Liikenne- ja viestintäministeriö (2007). Viestintäpolitiikka arjen tietoyhteiskunnassa. Saatavilla osoitteessa: http://www.mintc.fi/oliver/ upl947-Viestintäpolitiikka-esite.pdf (tarkistettu 6.4.2008)

Liikenne- ja viestintäministeriö (2008). Lasten ja nuorten mediafoorumin asettamispäätös 19.2.2008. Saatavilla osoitteessa: http:// www.arjentietoyhteiskunta.fi/ index.phtml?s=71 (tarkistettu 6.4.2008)

Liikkanen, M., Hanifi, R. \& Hannula, U. (toim.) (2005). Yksilöllisiä valintoja, kulttuurista pysyvyyttä. Vapaa-ajan muutokset 1981-2002. Helsinki: Tilastokeskus.

Mellor, D., Firth, L. \& Moore, K. (2008). Can the Internet improve the well-being of the elderly. Ageing International, 32(1), 25-42.

Mustonen, A. (2006). Mediakasvatusta kaikenikäisille. Aikuiskasvatus, 3(26), 236-241.

Niemelä, R. (2006). Ikääntyneiden informaatiokäyttäytyminen. Laadullinen tutkimus arkielämän informaatiokäytännöistä ja toimintaan aktivoitumisesta. Acta Universitatis Ouluensis, Humaniora B 74.

Niinistö, H. \& Ruhala, A. (2007). Pienten lasten mediakasvatus. Teoksessa: H. Kynäslahti, R. Kupiainen \& M. Lehtonen (toim.) Näkökulmia mediakasvatukseen. Mediakasvatusseuran julkaisuja 1/2007, 123-135.

Opetusministeriö (2007). Ehdotus toimenpideohjelmaksi mediataitojen ja -osaamisen kehittämiseksi osana kansalais-ja tietoyhteiskuntataitojen edistämistä. Opetusministeriön työryhmämuistioita ja selvityksiä 29/2007.
Saatavilla osoitteessa: http://www.minedu.fi/ OPM/Julkaisut/julkaisuhaku?lang=fi (tarkistettu 6.4.2008)

Raitanen, T., Hänninen, T., Pajunen, H. \& Suutama, T. (2004). Johdanto. Teoksessa: T. Raitanen, T. Hänninen, H. Pajunen \& T. Suutama (toim.) Geropsykologia. Helsinki: WSOY, 712.

Ruokamo, H. (2005). Näkökulmia mediakasvatuksen opetukseen ja tutkimukseen. Teoksessa: A. Niikko, M.-L. Julkunen \& M.-B. Kentz (toim.) Osaamisen jakamista kasvatustieteessä. Joensuu: Joensuun yliopisto, kasvatustieteiden tiedekunta, 131-153.

Sankari, A. (2004). Ikääntyviä tietoyhteiskunnassa: kulttuuriset ajattelutavat ja sosiaalinen tila. Jyväskylä: Minerva.

Selwyn, N. (2004). The information aged: a qualitative study of older adults' use of information and communications technology. Journal of Aging Studies, 18(4), 369-384.

Sintonen, S. (2001). Mediakasvatus ja sen musiikilliset mahdollisuudet. Studia Musica 11. Sibelius-Akatemia. Musiikkikasvatuksen osasto.

Suoranta, J. \& Ylä-Kotola, M. (2000). Mediakasvatus simulaatiokulttuurissa. Helsinki: WSOY.

Suoranta, J. (2006). Aikuisten mediatajun jäljillä. Aikuiskasvatus, 3(26), 211-220.

Tilastokeskus (2007). Internetiä käytti $79 \%$ väestöstä vuoden 2007 alussa. http:// www.stat.fi/til/sutivi/2007/sutivi_2007_200709-28_tie_001.html

Tuominen, S. \& Mustonen, A. (2007). Tunteella ja järjellä nettiin - Internetissä tarvitaan uudenlaisia mediataitoja. Teoksessa: H. Kynäslahti, R. Kupiainen \& M. Lehtonen (toim.) Näkökulmia mediakasvatukseen. Mediakasvatusseuran julkaisuja 1/2007, 137-150.

Tuorila, H. \& Kytö, H. (2005). Verkkopalvelut ikääntyvien hyvinvoinnin edistäjinä. Kuluttajatutkimuskeskus, julkaisuja 5:2005. Saatavilla osoitteessa: http://www.ncrc.fi/ index.phtml?s=3 (tarkistettu 23.3.2008)

Vesterinen, O., Vahtivuori-Hänninen, S., Oksanen, U., Uusitalo, A. \& Kynäslahti, H. (2006). Mediakasvatus median ja kasvatuksen alueena - Deskriptiivisen mediakasvatuksen ja didaktiikan näkökulmia. Kasvatus, 37(2), 148161. 